\title{
FAKTOR- FAKTOR YANG MEMPENGARUHI PENDAPATAN PETANI SALAK DI DESA PARSALAKAN ANGKOLA BARAT TAPANULI SELATAN
}

\author{
Nora Efrita Nasution \\ Alumni Jurusan Manajemen Fakultas Ekonomi Universitas Negeri Medan \\ Edison Sagala \\ Dosen Jurusan Manajemen Fakultas Ekonomi Universitas Negeri Medan
}

\begin{abstract}
Factors of production farming has a different function to level of production and farmers income. The better use factors of production, the amount of production is produced also more and more so that income received by farmers is higher. This study aims to determine whether education, experience, land, and capital affect farmers' income. The population in this study were all barking farmers in the village of Persalakan Angkola Barat South Tapanuli. The sampling technique in studies using methods Solvin with a total sample of 50 farmers bark. Data collection techniques used observation and questionnaires. The data analysis technique used is multiple linear analysis to prioritize testing and classical assumption of normality as a condition of continued analysis. From the results of analysis can be concluded the factor of land area education and partially no effect on farmers 'income while the experience factor, capital, Extension and Number of dependents has a positive and significant impact on farmers' income in the village of Persalakan Angkola Barat South Tapanuli.
\end{abstract}

Keywords: $\quad$ Education, Experience, Land, Capital, Counseling, Number of dependents, income

\section{PENDAHULUAN}

Komoditas horticultural yang dibudidayakan di Indonesia sangat banyak jenis anekanya. Meliputi tanaman sayur-sayuran, buah-buahan, bunga-bungaan, dan tanaman hias. Komoditas tersebut diusahakan dari tingkat desa hingga ketengah-tengah perkotaan.Komoditas horticultural sudah banyak dihasilkan di dataran tinggi kabupaten tapanuli selatan .Salak merupakan salah satu komoditas yang banyak dihasilkan.

Tanaman salak tidak asing lagi bagi masyarakat, karena seharihari selalu ada tanpa mengenal musim. Selain itu masyarakat sudah membudidayakan salak sebagai usaha pertanian yang menguntungkan. Pengembangan budidaya salak baik melalui ekstensifikasi maupun intensifikasi, akan berdampak positif bagi kehidupan masyarakat, yaitu memberikan kesempatan kerja yang luas, memberikan penghasilan bagi masyarakat pada setiap rantai agribisnis, dan meningkatkan perbaikan gizi masyarakat. Pengembangan budidaya salak di tapsel di dukung oleh keadaan agroklimatologi dan agroekonomi wilayah yang sesuai (Cahyono,2002: 14)

Prospek pengembangan budidaya salak di tapsel sangat berpotensi, selain keadaan agroklimatologis wilayah nusantara cocok untuk salak, juga akan berdampak positip terhadap peningkatan pendapatan petani, perluasan kesempatan kerja, 
pengembangan

(Rukmana,1995 : 13)

Dari pengamatan dan

wawancara yang dilakukan dilapangan, ada beberapa masalah yang ada di masyarakat petani salak yaitu :

1. Rendahnya pendidikan petani sehingga usahanya tidak berkembang secara baik

2. Umur petani yang tidak muda lagi 3. Penyuluhan yang kurang dilakukan oleh pemerintah daerah.

4. Lahan petani yang sempit

5. Jumlah tanggungan petani yang banyak.

6. Modal yang kecil dalam menjalankan usaha pertanian.

Desa angkola merupakan daerah penghasil salak yang cukup berpotensi di sumatera utara, khususnya kecamatan angkola karena sebagaian besar penduduknya bermata pencaharian sebagai petani salak, Salah satu buah yang dihasilkan daerah ini adalah salak.

Namun, penyuluhan dalam pertanian dinilai masih kurang dari pemerintah daerah khususnya salak yang merupakan komoditas andalan daerah ini. Hal ini seharusnya tidak terjadi mengingat sekarang sudah di terapkan otonomi daerah sehingga pemerintah daerah harus fokus terhadap komoditas unggulan daerah yang akan menjadi sumber pendapatan daerah.

\section{METODE PENELITIAN \\ Lokasi Penelitian}

Penelitian ini dilakukan di desa Parsalakan Angkola Barat Tapanuli Selatan.

\section{Populasi dan Sampel}

Populasi yang digunakan dalam penelitian ini adalah semua petani salak yang ada di desa parsalakan angkola barat tapanuli selatan sebanyak 100 orang, sedangkan sampel yang digunakan dalam penelitian adalah petani salak yang ada di desa parsalakan angkola barat tapanuli selatan yang digunakan Simple Random Sampling.

Alasan dari pengambilan secara Simple Random Sampling adalah dikarenakan di daerah penelitian patani memiliki luas lahan yang cukup beragam yaitu antara 0,25-1,5 ha. Hal ini akan memudahkan dalam penentuan dan kevaliditasan data atau dalam hal terjadinya kebiasaan data dari petani yang lainnya dikarenakan keadaan luas lahan yang dimiliki.

Untuk menghitung ukuran sampel didasarkan pada pendungaan proporsi populasi dengan rumus Slovin sebagai berikut:

$$
\boldsymbol{n}=\frac{\mathrm{N}}{\mathrm{Nd}^{2}+\mathbf{1}} \quad \text { (Riduwan, 2007:65) }
$$

Dimana : $\mathrm{n}=$ sampel,, $\mathrm{N}=$ populasi, $\mathrm{d}=$ standar eror

Jumlah populasi 100 petani salak, dengan standar eror $10 \%$.dengan demikian, jumlah sampel yang di ambil:

$$
\begin{aligned}
n & =\frac{100}{100(0,1)^{2}+1} \\
& =50
\end{aligned}
$$

Jadi jumlah sampel yang diambil sebanyak 50 orang

Variabel Penelitian dan Defenisi Operasionel

Variabel Penelitian

a. Variabel X (bebas),adalah

- Pendidikan (X1)

- Pengalaman (X2)

- Lahan (X3)

- Modal (X4)

- Penyuluhan (X5)

- Jumlah tanggungan (X6) 
b. Variabel Y (terikat), adalah pendapatan petani salak.

\section{Defenisi Operasionel}

Untuk menjelaskan dan menghindari kesalahpahaman dalam penelitian ini maka deberi defenisi operasional sebagai berikut :

1. Pendidikan yang di maksud adalah pendidikan formal yang dimiliki atau ditempuh oleh petani yang diukur berdasarkan tingkat SD,SMP,SMA,S1.

2. Pengalaman dalam hal ini adalah pengalaman seorang petani bekerja atau mengelola usahatani salak,yang dinyatakan dalam satu (tahun).

3. Lahan dalam hal ini adalah lahan yang digunakan petani dalam mengelola usahatani yang dinyatakan dalam hektar (Ha).

4. Modal dalam hal ini adalah sejumlah dana yang digunakan untuk mengelola usahatani salak yang dinyatakan dalam rupiah (Rp).

5. Penyuluhan dalam hal ini adalah lamanya petani mengikuti penyuluhan yang berhubungan dengan usaha pertanian salak.

6. Jumlah tanggungan adalah banyaknya orang yang di tanggung dan dibiayai oleh kepala rumah tangga keluarga itu.

7. Pendapat adalah total pertanian usahatani salak dikurang total biaya yang dikeluarkan yang dinyatakan dalam rupiah $(\mathrm{Rp})$.

\section{Analisis Regresi Linier Berganda.}

Analisis Regresi Linier Berganda yang digunakan dalam penelitian ini untuk mengetahui seberapa besar faktor-faktor yang mempengaruhui pendapatan petani dengan menggunakan rumus regresi linier berganda.menurut Kuncoro (2003:215).

Regresi linier berganda bertujuan untuk melihat secara langsung pengaruh beberapa variabel bebas terhadap variabel terikat.

Persamaan regresi linier berganda dapat ditulis sebagai berikut :

$\mathbf{Y}=\mathbf{a}+\mathbf{b}_{1} \mathbf{X}_{2}+\mathbf{b}_{2} \mathbf{X}_{2}+\mathbf{b}_{3} \mathbf{X}_{3}+\mathbf{b}_{4} \mathbf{X}_{4}$ $+b_{5} X_{5}+e$

Dimana :

Y : Pendapatan

$\mathrm{X} 1$ : Pendidikan (tahun)

$\mathrm{X} 2$ : Pengalaman (tahun)

X3: Lahan (Ha)

X4: Modal (Rp)

X5 : Penyuluhan (Tahun)

$\mathrm{X} 6$ : Jumlah tanggungan (Orang)

a : Konstanta

$\mathrm{b}:$ Koefisien regresi

c : Eror

Uji Hipotesis

Uji F

Uji F dilakukan untuk membuktikan hipotesis awal tentang pengaruh pendidikan (X1), pengalaman (X2), lahan (X3), modal (X4), penyuluhan (X5), dan jumlah tanggungan (X6), secara bersamasama (simultan) sebagai variabel bebas terhadap pendapatan petani (Y) sebagai variabel terikat dengan rumus sebagai berikut (Sugiyono,2006:190)

$$
F h=\frac{R^{2} / k}{\left(1-R^{2}\right) /(n-k-1)}
$$


Dimana :

$\mathrm{R}=$ koefesien korelasi ganda

$\mathrm{K}=$ jumlah variabel independen

$\mathrm{n}=$ jumlah sampel

Untuk mengetahui besarnya keseragaman $\mathrm{Y}$ yang dapat diterangkan oleh variabel $\mathrm{X}$ digunakan koefisien determinasi atau $\mathrm{R}^{2}$.

Uji t

Untuk menguji secara varsial apakah variabel bebas $(\mathrm{X} 1, \mathrm{X} 2, \mathrm{X} 3, \mathrm{X} 4, \mathrm{X} 5, \mathrm{X} 6) \quad$ memiliki pengaruh yang signifikan terhadap variabel bterikat (Y),maka penelitian menggunakan rumus sebagai berikut (Riduwan,2007:125).

Dimana :

$\mathrm{t}=$ signifikan parsial

$\mathrm{r}=$ koefesian korelasi parsial

$\mathrm{n}=$ jumlah sampel/responden

Terima Ho : jika t-hit $\leq \mathrm{t}$-tab, artinya variabel $\mathrm{X}$ (pendidikan, pengalaman, luas lahan, modal, penyuluha, dan jumlah tanggungan) secara parsial berpengaruh tidak nyata terhadap Y(pendapatan).

Tolak Ho : jika t-hit $>$ ttab,artinya variable $\mathrm{X}$ (pendidikan, pengalaman, luas lahan, modal, penyuluhan, dan jumlah tanggungan) secara parsial berpengaruh nyata terhadap Y(pendapatan).

Kriteria pengambilan keputusannya adalah sebagai berikut :

Ho diterima Jika thitung $<\mathrm{t}_{\text {tabel }}$, pada $\alpha$ $=5 \%$

Ho ditolak Jika thitung $>t_{\text {tabel, }}$ pada $\alpha=$ $5 \%$

\section{Uji Koefisien Determinan $\left(R^{2}\right)$.}

Uji ini digunakan untuk melihat kontribusi variabel bebas, yaitu pendidikan(X1), pengalaman (X2), lahan (X3), modal (X4), penyuluha (X5), dan jumlah tanggungan (X6),terhadap pendapatan petani (Y) sebagai variabel terikat. Untuk mengukur uji koefisien determinan dapat digunakan rumus sebagai berikut:

$R^{2}=\frac{(\mathrm{n} \mathrm{\Sigma X} \mathrm{1,2,3,4,Y})-\left(\mathrm{\Sigma X} \mathrm{1}_{1}, 2,3,4,\right)(\mathrm{\Sigma Y})}{\mathrm{n}\left(\Sigma \mathrm{\Sigma Y}^{2}\right)-(\Sigma \mathrm{YY})^{2}}$

Pengujian-pengujian diatas dilakukan dengan bantuan program pengolahan data Statistical Packages Sosial Science (SPSS) 15,0.

\section{HASIL PENELITIAN DAN PEMBAHASAN \\ Hasil Penelitian \\ Analisis Regresi}

Pengolahan data dengan menggunakan regresi linear dilakukan dalam beberapa tahapan untuk mencari hubungan antara variabel independen dan variabel dependen, melalui pengaruh pendidikan, pengalaman, lahan, modal, penyuluhan, dan jumlah tanggungan terhadap pendapatan. Berikut ini adalah hasil regresi yang disajikan dalam bentuk tabel.

Berdasarkan hasil perhitungan diperoleh hasil persamaan regresi ganda adalah sebagai berikut :

Tabel 1. Hasil Perhitungan Regresi Linear Berganda Coefficients $^{\mathrm{a}}$

\begin{tabular}{|c|c|c|c|c|c|}
\hline \multirow[b]{2}{*}{ Model } & \multicolumn{2}{|c|}{$\begin{array}{c}\text { Unstandardiz } \\
\text { ed } \\
\text { Coefficients }\end{array}$} & \multirow{2}{*}{$\begin{array}{c}\begin{array}{c}\text { Standardiz } \\
\text { ed } \\
\text { Coefficient } \\
\mathrm{S}\end{array} \\
\\
\text { Beta }\end{array}$} & \multirow[b]{2}{*}{$\mathrm{t}$} & \multirow[b]{2}{*}{ Sig } \\
\hline & B & $\begin{array}{l}\text { Std. } \\
\text { Error }\end{array}$ & & & \\
\hline 1 (Constant) & 4.116 & $\begin{array}{r}5.26 \\
8\end{array}$ & & .781 & $\begin{array}{r}.43 \\
9\end{array}$ \\
\hline $\begin{array}{l}\text { Pendidika } \\
\mathrm{n}\end{array}$ & .012 & .033 & .021 & .362 & $\begin{array}{r}.71 \\
9\end{array}$ \\
\hline $\begin{array}{l}\text { Pengalam } \\
\text { an }\end{array}$ & .027 & .012 & .154 & $\begin{array}{r}2.24 \\
1\end{array}$ & $\begin{array}{r}.03 \\
0\end{array}$ \\
\hline $\begin{array}{l}\text { Luas } \\
\text { Lahan }\end{array}$ & .076 & .139 & .108 & .550 & $\begin{array}{r}.58 \\
5\end{array}$ \\
\hline
\end{tabular}




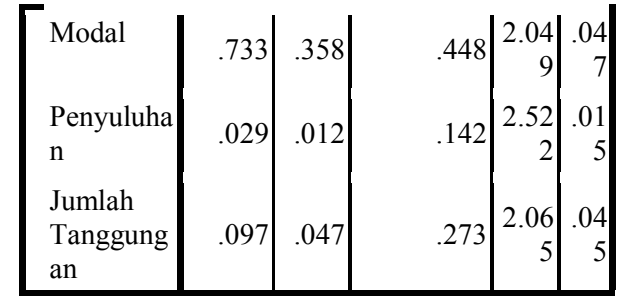

a. Dependent Variable:

Pendapatan

Sumber : Hasil Pengolahan SPSS

Dari data hasil SPSS di atas dapat dijelaskan sebagai berikut :

$\hat{\mathbf{Y}}=4,116+0,012 X_{1}+0,027 X_{2}+0,076$

$\mathrm{X}_{3}+0,733 \mathrm{X}_{4}+0,029 \mathrm{X}_{5}+0,097 \mathrm{X}_{6}+\mathrm{e}$

- Konstanta sebesar 4,482 berarti bahwa Pendapatan petani salak akan konstan sebesar 4,482 jika tidak dipengaruhi variabel Independen (pendidikan, pengalaman, lahan, modal, penyuluhan, jumlah tanggungan)

- Koefisien regresi $b_{1}$ sebesar 0,012 menunjukkan bahwa jika pendidikan petani meningkat sebesar 1 satuan, maka pendapatan petani akan meningkat sebesar 0,012 dengan asumsi variabel lain tetap

- Koefisien regresi $b_{2}$ sebesar 0,027 menunjukkan bahwa jika pengalaman petani meningkat sebesar 1 satuan, maka pendapatan petani akan meningkat sebesar 0,027 dengan asumsi variabel lain tetap

- Koefisien regresi $b_{3}$ sebesar 0,076 menunjukkan bahwa jika luas lahan petani meningkat sebesar 1 satuan, maka pendapatan petani akan meningkat sebesar 0,076 dengan asumsi variabel lain tetap

- Koefisien regresi $b_{4}$ sebesar 0,733 menunjukkan bahwa jika modal petani meningkat sebesar $1 \%$, maka pendapatan petani akan meningkat sebesar $73,3 \%$ dengan asumsi variabel lain tetap
- $\quad$ Koefisien regresi $b_{5}$ sebesar 0,029 menunjukkan bahwa jika penyuluhan pada petani meningkat sebesar 1 satuan, maka pendapatan petani akan meningkat sebesar 0,029 dengan asumsi variabel lain tetap

- Koefisien regresi $b_{6}$ sebesar 0,097 menunjukkan bahwa jika jumlah tanggungan (pekerja) pada petani meningkat sebesar 1 satuan, maka pendapatan petani akan meningkat sebesar 0,097 dengan asumsi variabel lain tetap

\section{Pengujian Hipotesis Penelitian}

Pengujian hipotesis penelitian dilakukan untuk menguji keempat hipotesis penelitian yang telah dipaparkan sebelumnya. Untuk mengetahui apakah variabel independen dalam model regresi berpengaruh terhadap variabel dependen, maka dilakukan pengujian dengan menggunakan uji $\mathrm{t}(\mathrm{t}$ test) dan uji F (F test).

\section{Uji t (Uji Regresi Parsial)}

Uji statistik t dilakukan untuk menguji pengaruh dari variabel independen terhadap variabel dependennya secara individu. Hal ini dapat dilihat dari nilai signifikan $\mathrm{t}$ yang dihasilkan dari perhitungan. Apabila nilai signifikan $\mathrm{t}<$ tingkat signifikan (0.05) maka variabel independen secara individu berpengaruh terhadap variabel dependennya, sebaliknya jika nilai signifikan $\mathrm{t}>$ tingkat signifikansi (0.05) maka variabel independennya secara individu tidak berpengaruh terhadap variabel dependennya. Berdasarkan hasil pengolahan SPSS versi 16, diperoleh hasil sebagai berikut : 
Tabel 2. Hasil Uji t

Coefficients $^{\mathrm{a}}$

\begin{tabular}{|c|c|c|c|c|c|}
\hline \multirow[b]{2}{*}{ Model } & \multicolumn{2}{|c|}{$\begin{array}{c}\text { Unstandardiz } \\
\text { ed } \\
\text { Coefficients }\end{array}$} & \multirow{2}{*}{$\begin{array}{c}\begin{array}{c}\text { Standardiz } \\
\text { ed } \\
\text { Coefficient } \\
\mathrm{s}\end{array} \\
\\
\text { Beta }\end{array}$} & \multirow[b]{2}{*}{$\mathrm{t}$} & \multirow[b]{2}{*}{ Sig } \\
\hline & B & $\begin{array}{l}\text { Std. } \\
\text { Error }\end{array}$ & & & \\
\hline 1 (Constant) & 4.116 & 5.268 & & .781 & $\begin{array}{r}.43 \\
9\end{array}$ \\
\hline $\begin{array}{l}\text { Pendidika } \\
\mathrm{n}\end{array}$ & .012 & .033 & .021 & .362 & $\begin{array}{r}.71 \\
9\end{array}$ \\
\hline $\begin{array}{l}\text { Pengalam } \\
\text { an }\end{array}$ & .027 & .012 & .154 & $\begin{array}{r}2.24 \\
1\end{array}$ & $\begin{array}{r}.03 \\
0\end{array}$ \\
\hline $\begin{array}{l}\text { Luas } \\
\text { Lahan }\end{array}$ & .076 & .139 & .108 & .550 & $\begin{array}{r}.58 \\
5\end{array}$ \\
\hline Modal & .733 & .358 & .448 & $\begin{array}{r}2.04 \\
9\end{array}$ & $\begin{array}{r}.04 \\
7\end{array}$ \\
\hline $\begin{array}{l}\text { Penyuluha } \\
\mathrm{n}\end{array}$ & .029 & .012 & .142 & $\begin{array}{r}2.52 \\
2\end{array}$ & $\begin{array}{r}.01 \\
5\end{array}$ \\
\hline $\begin{array}{l}\text { Jumlah } \\
\text { Tanggung } \\
\text { an }\end{array}$ & .097 & .047 & .273 & $\begin{array}{r}2.06 \\
5\end{array}$ & $\begin{array}{r}.04 \\
5\end{array}$ \\
\hline
\end{tabular}

a. Dependent Variable:

Pendapatan

Sumber : Hasil Pengolahan SPSS

$\mathrm{H}_{1}$ : Faktor Pendidikan berpengaruh terhadap Pendapatan Petani Salak

Hasil uji statistik menunjukkan bahwa t-hitung adalah 0,362, sedangkan t-tabel adalah 2,00, sehingga t-hitung $<$ t-tabel $(0,362<$ 2,00). Signifikansi penelitian ini menunjukkan angka yang lebih besar dari $0,05(0,719>0,05)$, maka dapat disimpulkan bahwa tidak terdapat pengaruh pendidikan terhadap terhadap Pendapatan Petani Salak. Hal ini dikarenakan petani yang berpendidikan tinggi atau rendah sama-sama berpeluang dalam pertanian salak. Pendidikan formal petani yang umumnya sekolah dasar tidak diajarkan mengenai suatu inovasi yang terkait pertanian selain itu pendidikan tinggi yang dimiliki petani bukan mengenai pertanian. Pengetahuan pertanian baru diperoleh melalui pendidikan non formal seperti penyuluhan maupun pelatihan atau percobaan dilapangan, oleh karena itu meskipun pendidikan formal yang dimiliki cukup tetapi tidak dibarengi dengan pendidikan non formal yang baik maka tidak mempunyai pengetahuan yang baik terhadap inovasi bidang pertanian.

$\mathrm{H}_{2}$ : Faktor Pengalaman berpengaruh terhadap Pendapatan Petani Salak

Hasil uji statistik tersebut menunjukkan bahwa t-hitung adalah 2,241, sedangkan t-tabel adalah 2,00, sehingga t-hitung $>$ t-tabel $(2,241>$ 2,00). Signifikansi penelitian ini menunjukkan angka yang lebih kecil dari $0,05(0,030<0,05)$, maka dapat disimpulkan bahwa terdapat pengaruh positif dan signifikan antara faktor pengalaman terhadap terhadap Pendapatan Petani Salak. Semakin banyak pengalaman yang diperoleh oleh petani, maka minat mereka terhadap usahatani salak semakin tinggi, dengan banyaknya pengalaman yang telah mereka lalui, maka banyak cara yang dapat mereka lakukan untuk menaikkan produksi panen.

$\mathrm{H}_{3}$ : Faktor Luas Lahan berpengaruh terhadap Pendapatan Petani Salak

Hasil uji statistik tersebut menunjukkan bahwa t-hitung adalah 0,550 , sedangkan t-tabel adalah 2,00, sehingga t-hitung $<\mathrm{t}$-tabel $(0,550>$ 2,00). Signifikansi penelitian ini menunjukkan angka yang lebih besar dari $0,05(0,585>0,05)$, maka dapat disimpulkan bahwa tidak terdapat pengaruh luas lahan terhadap terhadap Pendapatan Petani Salak. Luas lahan yang digarap tidak saja secara langsung berpengaruh terhadap 
pendapatan petani, tetapi juga akan mempengaruhi sistem pengelolaan (manajemen) usaha tani, yang kemudian berpengaruh terhadap penggunaan modal dan faktor produksi lain dan akhirnya akan berpengaruh terhadap pendapatan petani.

$\mathrm{H}_{4}$ : Faktor Modal berpengaruh terhadap Pendapatan Petani Salak

Hasil uji statistik tersebut menunjukkan bahwa t-hitung adalah 2,049, sedangkan t-tabel adalah 2,00, sehingga t-hitung $>$ t-tabel $(2,049>$ 2,00). Signifikansi penelitian ini menunjukkan angka yang lebih kecil dari $0,05(0,047<0,05)$, maka dapat disimpulkan bahwa terdapat pengaruh positif dan signifikan antara faktor modal terhadap terhadap Pendapatan Petani Salak.

$\mathrm{H}_{5}$ : Faktor penyuluhan berpengaruh terhadap Pendapatan Petani Salak

Hasil uji statistik tersebut menunjukkan bahwa t-hitung adalah 2,522, sedangkan t-tabel adalah 2,00, sehingga t-hitung $>$ t-tabel $(2,522>$ 2,00). Signifikansi penelitian ini menunjukkan angka yang lebih kecil dari $0,05(0,015<0,05)$, maka dapat disimpulkan bahwa terdapat pengaruh positif dan signifikan antara faktor penyuluhan terhadap terhadap Pendapatan Petani Salak. Pendapatan petani dipengaruhi oleh frekuensi petani mengikuti kegiatan penyuluhan pertanian Penyuluhan telah berhasil menyampaikan berbagai inovasi pertanian kepada petani dengan segala metodenya sehingga terjadi peningkatan pendapatan petani.
$\mathrm{H}_{6}$ : Faktor Jumlah Tanggungan berpengaruh terhadap Pendapatan Petani Salak

Dari tabel regresi dapat dilihat besarnya t-hitung untuk variabel jumlah tanggungan sebesar 2,065 dengan nilai signifikansi 0,045 . Hasil uji statistik tersebut menunjukkan bahwa t-hitung adalah 2,065, sedangkan t-tabel adalah 2,00, sehingga t-hitung $>$ t-tabel $(2,065>$ 2,00). Signifikansi penelitian ini menunjukkan angka yang lebih kecil dari $0,05(0,045<0,05)$, maka dapat disimpulkan bahwa terdapat pengaruh positif dan signifikan antara faktor jumlah tanggungan terhadap terhadap Pendapatan Petani Salak.

\section{Uji Simultan (Uji F)}

Berdasarkan hasil pengujian statistik (Uji ANOVA/Uji F) dapat dilihat pada tabel output berikut :

Tabel 3. Hasil Perhitungan Uji

Anova

ANOVA $^{b}$

\begin{tabular}{|l|r|r|r|l|l|}
\hline Model & $\begin{array}{r}\text { Sum of } \\
\text { Squares }\end{array}$ & df & $\begin{array}{c}\text { Mean } \\
\text { Square }\end{array}$ & F & Sig. \\
\hline 1 Regression & 8.826 & 6 & 1.471 & 50.008 & $.000^{\mathrm{a}}$ \\
Residual & 1.265 & 43 & .029 & & \\
Total & 10.091 & 49 & & & \\
\hline
\end{tabular}

a. Predictors: (Constant), Jumlah

Tanggungan, Penyuluhan, Pendidikan,

Pengalaman, Luas Lahan, Modal

b. Dependent Variable:

Pendapatan

Sumber : Hasil Pengolahan SPSS

Pada tabel di atas diperoleh

bahwa nilai $\mathrm{Uji} \quad \mathrm{F}_{\text {hitung }}=50,008$ dengan tingkat probability $(0,000<$ $0,05)$. Setelah mengetahui besarnya $F_{\text {hitung, maka akan dibandingkan }}$ dengan $\mathrm{F}_{\text {tabel. }}$. Adapun hasil $\mathrm{F}_{\text {tabel }}$ diperoleh dengan $\mathrm{F}_{(1-\alpha)[(\mathrm{dk}=6),(\mathrm{dk}=50-2-1)}$ $=\mathrm{F}_{(1-\alpha)(6,43)}$ adalah 2,318. Maka $F_{\text {hitung }}(50,008)>F_{\text {tabel }}(2,318)$ atau Ho 
ditolak dan $\mathrm{Ha}$ diterima artinya koefisien regresi ganda adalah signifikan. Dengan demikian bahwa faktor pendidikan, pengalaman, lahan, modal, penyuluhan, dan jumlah tanggungan secara simultan berpengaruh signifikan terhadap pendapatan petani salak di desa Parsalakan Angkola Barat Tapanuli Selatan.

\section{Koefisien Determinasi $\left(\mathbf{R}^{2}\right)$ \\ Tabel 4. Koefisien Determinasi (R square)} Model Summary ${ }^{\mathrm{b}}$

\begin{tabular}{|l|c|r|r|c|}
\hline Model & $\mathrm{R}$ & $\begin{array}{c}\mathrm{R} \\
\text { Square }\end{array}$ & $\begin{array}{c}\text { Adjusted } \\
\mathrm{R} \\
\text { Square }\end{array}$ & $\begin{array}{c}\text { Std. Error of the } \\
\text { Estimate }\end{array}$ \\
\hline 1 & $.935^{\mathrm{a}}$ & .875 & .857 & .17151 \\
\hline
\end{tabular}

a. Predictors: (Constant), Jumlah

Tanggungan, Penyuluhan, Pendidikan,

Pengalaman, Luas Lahan, Modal

b. Dependent Variable: Pendapatan

Sumber : Hasil Pengolahan SPSS

Angka R sebesar 0,935 menunjukkan bahwa korelasi atau hubungan yang kuat antara variabel faktor pendidikan, pengalaman, lahan, modal, penyuluhan, dan jumlah tanggungan dengan pendapatan petani salak sebesar 93,5\%. Angka R square 0,875 artinya variabel-variabel bebas (faktor pendidikan, pengalaman, lahan, modal, penyuluhan, dan jumlah tanggungan) mampu menjelaskan variabel terikat (pendapatan petani salak) sebesar $87,5 \%$ dan sisanya $12,5 \%$ variabel pendapatan petani salak dijelaskan oleh variabel lain diluar penelitian.

\section{Pembahasan Hasil Penelitian}

Berdasarkan hasil penelitian
tentang faktor-faktor yang mempengaruhi pendapatan petani salak di Desa Parsalakan Angkola Barat Tapanuli Selatan diketahui bahwa luas lahan minimum yang di miliki petani salak seluas $0,5 \mathrm{Ha}$ sedangkan luas lahan maksimum yang dimiliki patani salak seluas 3 Ha. Rata-rata luas lahan yang dimiliki petani salakdi Desa Parsalakan Angkola Barat Tapanuli Selatan seluas 1,31 Ha. Modal yang dikeluarkan oleh petani salak dalam mengelola pertanian salak minimum ssebesar Rp.2.89.000 dan maksimium sebesar Rp.9.253.000. Rata-rata modal yang dikeluarkan petani salak dalam mengelola pertanian salaknya Rp.4.937.632.Hal ini menunjukkan modal yang dikeluarkan petani salak sudah cukup untuk mengelolah lahan pertanian,benih, pupuk dan perawatan pertanian. Besar pendapatan minimum yang diperoleh petani setiap musim panen sebesar Rp 5.400 .000 dan maksimum Rp.29.250.000. pendapatan rata-rata yang diperoleh petani salak setiap musim panen salak sebesar Rp.13.972.500.

Hasil pengujian hipotesis menunjukkan bahwa variabel pendidikan dan luas lahan secara parsial mempunyai pengaruh terhadap pendapatan patani salak. Hal ini dapat terlihat dari tingkat signifikan variabel pendidikan dan luas lahan pada uji koefisien regresi dimana nilai signifikan lebih besar dari taraf signifikan $5 \quad \% \quad(0,05)$. Dengan demikian penelitian ini menerima hipotesis yang menyatakan bahwa faktor pendidikan dan luas lahan tidak berpengaruh pendapatan petani salak di Desa Parsalakan Angkola Barat Tapanuli Selatan. Sedangkan untuk variabel

pengalaman,modal,penyuluhan, dan jumlah tanggungan memiliki pengaruh positif dan signifikan terhadap pendapatan petani salak. Hal 
ini dapat terlihat dari tingkat signifikan variabel pengalaman,modal,penyuluhan dan jumlah tanggungan pada uji koefisien dimana nilai signifikan lebih kecil dariu garaf signifikan 5\% $(0,05)$.

Berdasarkan hasil koefisien regresi diperoleh bahwa faktor modal memiliki pengaruh yang lebih besar dalam mempengaruhi pendapatan petani salak,dibandingkan dengan faktor lain yaitu sebesar 0,733 atau $73,3 \%$. Modal merupakan salah satu faktor yang sangat penting dalam mendukung produksi pertanian dalam arti sumbangannya pada pendapatan petani. Tersediannya modal yang cukup untuk memulai petani mampu bekerja secara maksimal.

Berdasarkan hasil uji ANOVA dan $\mathrm{F}$ test menunjukkan Fhitung sebesar 50,008 dengan tingkat segnifikan 0,000, sedangkan Ftabel sebesar 2,318 dengan signifikansi 0,05 . Berdasarkan hasil tersebut dapat disimpulkan bahwa $\mathrm{Ha}$ diterima artinya koefisien regresi ganda adalah signifikan. Dengan demikian bahwa faktor

pendidikan,pengalaman,lahan,modal, penyuluhan,dan jumlah tanggungan secara simultan berpengaruh signifikan terhadap pendapatan petani salak di Desa Parsakaan Angkola Barat Tapanuli Selatan.

\section{PENUTUP}

Hasil perhitungan dan analisis yang telah diperoleh menunjukkan bahwa ada tiga kesimpulan yang dapat diambil yaitu :

1. Faktor pendidikan dan luas lahan secara parsial tidak berpengaruh terhadap pendapatan petani salak di desa parsalakan angkola barat tapanuli selatan. Hal ini dapat terlihat dari tingkat signifikan variabel pendidikan dan luas lahan pada uji koefisien regresi dimana nilai signifikansi lebih besar dari taraf signifikansi 5\% $(0,05)$

2. Faktor pengalaman, modal,penyuluhan dan jumlah tanggungan memiliki pengaruh positif dan signifikan terhadap pendapatan petani salak.hal ini dapat terlihat dari tingkat signifikan variabel pengalaman,modal,penyuluhan dan jumlah tanggungan pada uji koefisien regresi dimana nilai signifikansi lebih kecil dari taraf signifikansi 5\% $(0,05)$.

3. Berdasrkan hasil uji $F$ menunjukkan faktor pendidikan, pengalaman, lahan, modal, penyuluhan, dan jumlah tanggungan secara simultan berpengaruh signifikan terhadap pendapatan petani salak di Desa Parsalakan Angkola Barat Tapanuli Selatan.

\section{DAFTAR PUSTAKA}

Agus. 2004. “ Kondisi Sosial Ekonomi Masyarakat di Kelurahan Dwikora Kecamatan Medan Helvetie".Universitas Negeri Medan.Skripsi.Tidak Dipublikasikan.

Asngari, P.S.2003.Pentingnya Memahami Filsafah

Penyuluhan Pengembangan

Dalam Rangka Pemberdayaan Masyarakat. Bogor :IPB Press.
Badan Pusat Statistik Indonesia,2009.(Bps.go.id).
Cahyono B,2002.Salak Tehnik Budaya dan Analisis Usaha Tani. Kanisius Yogyakarta. 
E-journal

Universitas

Udayana,2010.http://ejournal.un ud.ac.id.

Husein,Umar.2005.

Metode

Penelitian Untuk Skripsi dan Tesis Bisnis.Jakarta:PT. Raja Grafindo.

Husodo,dkk.2004.Pertanian Mandiri. Jakarta:Penebar Swadaya.

Kementrian

Pertanian, 2010.(Kemetan.go.id).

Lubis,Moctar. 2002. Mencapai Pertanian Yang Lebih Baik.Jakarta : Yayasan Obor Indonesia.

Mubyarto.2001.Membangun Sistem Ekonomi. Yogyakarta:BPFE

Pambudy, R. 20003. Penyuluhan Dalam Sistem dan Usaha Agribisnis: Strategi Pengembagan Modal Manusia Indonesia. Bogor: IPB Press (http://one.indoskripsi.com).

Prawirokusomo, Soeharto.2002.Ilmu Usaha Tani.Yogyakarta:BPFE

Purba,Jhon Riaman.2004. "Analisis Sosial Ekonomi Pengembangan Program Pengembangan Sapi Potong Dengan Sistem Gaduhan Desa Jati Kesuma, Kecamatan Namoo Rambe, Kabupaten Deli Serdang”. Skripsi Departemen Manajemen Usu.

Rahardi, Yovita H.Indriani \& Haryono.2001. Agribisnis Tanaman Buah. Jakarta: Penebar Swadaya.

Riduan dan Akdon.2007 Rumus dan Data Analisis Statistik Untuk Penelitian (AdministrasiBisnis-Pemerintah- SosialKebijakan-Ekonomi-HukumManajemen-Kesehatan). Bandung Alfabeta.
Rukmana R, 1995. Bertanam Salak.Kanisius Yogyakarta

Rustam. 2002.Refleksi 4 Tahun Reformasi. Bogor: Intisari Lokakarya Nasional Social Ferestry.

Sianturi, Jhon Hengky. 2008. “ Analisis Dampak Pengembangan Komoditas Gambir Sebagai Sentra Agribisnis Yang Berorientasi Eksport Terhadap Peningkatan Pendapatan Petani di Kabupaten Dairi". Skripsi Departemen Manajemen USU

Sitompul, Haposan Timbul. 2004. "Pengaruh Faktor Sosial Ekonomi Terhadap Tingkat Pendapatan Pedagang Rotan di Kelurahan Sei Kambing Kecamatan Medan Petisah, Kota Medan". Universitas HKBP Nomensen Medan. Skripsi. Tidak Dipublikasikan.

Soehardi, Sigit.2004. Azas-azas Akuntansi, Edisi Revisi Bagian Keempat.BPFE,UGM.Yogyakar ta.

Soekartawi. 2001. Pengembangan Pertanian.Jakarta: PT. Raja Grafindo Persada.

2003.Agribisnis Teori dan Aplikasinya.Jakarta:PT.Raja Grafindo.

Sugiyono. 2006. Metode Pendidkan Bisnis, Cetakan Kesembilan. Bandung: Alfabeta.

Sujarno. 2008. " Analisis FaktorFaktor Yang Mempengaruhi Pendapatan Nelayan Di Kabupaten Langkat".'Skripsi Departemen Manajemen USU.

Sumarna. 2006 Ilmu Usahatani. Jakarta: Penebar Swadaya.

Syafrudin. 2003. Pengaruh Media Cetak Dalam Proses Adopsi 
JURNAL PLANS

Penelitian Ilmu Manajemen \& Bisnis

ISSN: $1978-7057$

E-ISSN: 2527-306X

\& Difusi Inovasi Beternak Ayam Broiler di Kota Kediri. UG M.

Syam, Noor Muhammad, (1986) Sosiologi Pendidikan. Bandung,Angkasa.

Tan. 2003. Proses dan Metodologi Penelitian Sosial Ekonom Untuk Menunjang Rekayasa Teknologi Tepat Guna Spesifik Lokasi di BPTP. Puslit Sosial Ekonomi Bogor.

Ulistiyono.

2007.//

Ilmumanajemen, Wordpress.com. 